\title{
Making a Green World
}

\author{
Rajnish Sharma \\ (Department of Strategic and Regional Studies, University Of Jammu, India)
}

\begin{abstract}
Collective-action problems occur when it takes the inputs and efforts of multiple individuals in order to achieve joint outcomes and it is difficult to exclude beneficiaries of these actions from benefiting even if they do not contribute. Collective-action problems vary in scale from very small problems involving only a few individuals to extremely large problems involving global resources, such as the atmosphere and the oceans. Solving collective-action problems requires opening public and private spheres of activities ranging from the small to the very large so as to encourage effective problem solving.

Environmental problems and challenges require a multidisciplinary and serious study. It needs an integrated approach on economy, politics, ecology, social stability, sustainability and spatial planning. Environmental policies are the principal means by which societies attempt to adapt to ecological constraints, and to mediate between competing demands and values. various strategies can be adopted to make a green world like Sustainable development, Resource Conservation, Green Economy, Bio-regionalism, Ecological Citizenship, Green Democracy, Changing Lifestyles, Enegy Policies, Legislature, Voluntary Control and Green Values.
\end{abstract}

Sustainable development is a huge and complex challenge at least in ethical terms. The nature of this ethical challenge may be summarized in terms of the three types of obligation to which sustainable development relates: towards people who are already living, towards people who are not yet born and towards species other than humans..

The basic thrust of the Resource Conservation standpoint was to restrain the reckless exploitation of forests, soils, etc., characteristic of the pioneer stage of modern social development by imposing ethical and legal requirements that natural resources be used wisely, meaning (in Gifford Pinchot's words)that they should be used "for the greatest good of the greatest number" (of humans), as distinct from being used to profit a few, and that the good should be considered in "the long run," that is, in terms of a sustainable society.

Most Green economists have tackled the problem of scale (i.e., the protection of ecological carrying capacity) by advocating (i) a range of new fiscal measures (such as resource depletion quotas and higher resource taxes and pollution charges) designed to control resource depletion and reduce material-energy throughput (ii) more comprehensive, and longer-range, environmental impact assessment and technology assessment and (iii) the replacement of indiscriminate GDP statistics with an alternative index of economic progress designed to provide a more meaningful yardstick by which to measure economic well-being.

Bioregionalism represents a specifically ecological rendition of the contemporary movement toward the break up of nation-states. It differs from the separatists on the ground that they demand the ecological preconditions of nationhood.

Environmental citizenship borrows the idea of transnational citizenship from the cosmopolitan tradition. Thus environmental citizenship speaks the language of obligation, of the common good and of the global reach of citizenship relations. In these respects it takes a rather different view of human motivation to the fiscal incentive strategy. It recognizes (or assumes) that people sometimes act in order to 'do good' as well as to try to ensure some gain for themselves.

Keywords: Adaptation, Anthroppogenic, Bioregionalism, Climate change, Collective action,Ecological citizenship, Eco-system, Emission, Greenhouse gases, Green economy, Kyoto Protocol, Resource conservation, Spritiual approach, Sustainable development, Values, Voluntarnism.

\section{Introduction}

The environmental crisis and popular environmental concern have prompted a considerable transformation in Western politics over the last three decades. This transformation has culminated in the development of new political cleavages, the formation of Green political parties, and the revision of old political platforms by the existing parties. Three major ecopolitical preoccupations are: participation, survival, and emancipation . The emergence of a general Green philosophy and Green political parties in the late 1970s and 1980 s may be seen as representing this third emancipatory moment.

The 1960s marked the beginning of widespread public concern over environmental degradation in the developed countries of the West. However, it took roughly a decade of persistent political agitation over such 
matters as pesticides, nuclear power plants, toxic waste dumps, large scale industrial developments, and pollution before an environmental crisis was officially recognized as a matter of local, national, and international concern. The mounting evidence of environmental degradation stemming from the exponential growth in resource consumption and human population was shown to pose very real threats to the earth's biological support systems. That is, the environmental crisis amounted to much more than a crisis of participation: what was at stake was the very survival of humanity. Degradation of Environment is also a cultural problem. Human beings are now endowed with the dominance of instrumental rationality. The cause of environmental degradation lies in western culture. It demands for re-evaluating the values. ${ }^{1}$

The three main objectives stated in the World Conservation Strategy (1980) are: the maintenance of essential ecological processes, the preservation of genetic diversity, and the sustainable utilization of natural resources. To achieve these objectives clearly requires social and economic interventions. The type of intervention open to environmental planners in developed countries varies according to the type of conflict over the environment. There are broadly three types of conflict: in the sphere of production, in the sphere of consumption and in the sphere of nature. In the sphere of production, intervention has been necessary to overcome market failure in the regulation of externality effects. Within industrial society capitalist firms seek to avoid the externalities of other producers, and to secure their access to essential natural resources.

Since the late nineteenth century the establishment of government resource agencies has sought to mediate conflicts within this area. Another type of intervention is in the sphere of natural conservation, where conflicts have been generated over the effects of modern agriculture on flora and fauna and their habitat. The situation in most developing countries is even less conducive to effective environmental interventions. This is partly because of the emphasis placed on project planning. Hosier and his colleagues argues that the methods employed in project planning, particularly cost-benefit analysis, are essentially means to minimize the risk to capital. $^{2}$

Environmental problems and challenges require a multidisciplinary and serious study. It needs an integrated approach on economy, politics, ecology, social stability, sustainability and spatial planning. Environmental policies are the principal means by which societies attempt to adapt to ecological constraints, and to mediate between competing demands and values. The strategies formulated by The National Environmental Assessment Agency are: a. Design and Implementation of ecological networks (green corridors and ecological zones). The establishment of green corridors and ecological zones are very important to support adaptation of species especially those with low migration capabilities. Ecological networks are a set of ecosystems, linked through robust corridors, providing space for species and allowing them to easily shift their habitat. b. Protected Areas should be screened on their suitability under changing climatic conditions. New protected areas can be developed through acquisition of land and change in land use. c. Adjustment of mix of tree species. The dispersal rates of trees is very slow compared to the expected speed of climatic changes and corridors may not be able to counteract the negative effects on some tree species, calling for active afforestation measures. Afforestation can contribute to create new green areas and increase the robustness of existing forest ecosystems. d. Artificial translocation of plants and animals is proposed as a way of preserving species under climate change. They also emphasize the importance of using various management approaches according to specie's climatic tolerances and dispersal abilities.

Like many other social problems, climate change is closely tied to the burning of oil, coal and gas. Fossil carbon is being taken out of the ground, run through combustion chambers, and transferred to a more active and rapidly circulating carbon pool in the air, oceans, vegetation and soil. Some of this active carbon builds up in the atmosphere in the form of carbon dioxide, trapping more of the sun's heat, warming the earth and destabilizing the climate. The difficulty is that fossil carbon is a lot easier to burn than it is to make. Among the likely manifestations of climate change in this century will be: less agricultural productivity, especially in hotter places, more frequent heat waves and less frequent cold spells, bigger storms, higher winds and more weather-related damage, more intense floods and, in mid-latitude continental interiors, droughts. Water crises associated with disappearing glaciers and snowpack's and other events, movement of farming to other regions, especially higher latitudes, faster disease transmission and other health impacts. Combined with the thermal expansion of the warmed oceans, this would ultimately cause a sea-level rise in excess of meters, flooding coastal cities and prime agricultural areas, species extinction and biodiversity loss, increased numbers of environmental refugees ${ }^{3}$.

The method of climate mitigation or adaptation can be adopted. Climate mitigation is any action taken to permanently eliminate or reduce the long term risk and hazards of climate change to human life, property. The international panel on Climate Change defines mitigation as: 'an anthropogenic intervention to reduce the

Robyn Eckersley, Environmentalism and political Theory- towards an ecocentric approach (London: UCL Press, 1992). Redcliff Michael, Sustainable development- exploring the contradictions (London and New York: Rutledge,1987).

Olle Nordberg, Carbon trading- a critical conversation on climate change, privatization and power, Development Dialogue ,48, 2006, 5-12. 
sources or enhance the sinks of greenhouse gases". Climate adaptation refers to the ability of a system to adjust to climate change to moderate potential damage. The Intergovernmental Panel on Climate Change( IPCC) defines adaptation as the adjustment in natural or human systems to a new or changing environment. Adaptation also is considered an important response option or strategy, along with mitigation. Even with the reductions in greenhouse gas emissions, global temperature continued to rise. Article-2 of the United Nation Framework on Climate Change Conference (UNFCCC) commits parties to formulating, cooperating on, and implementing measures to facilitate adequate adaptation to climate change. The Kyoto Protocol (Article10) also commits parties to promote and facilitate adaptation deploy adaptation technologies to address climate change. ${ }^{4}$

The objective of preventing average global temperature from rising by more than two degree Celsius requires that constructive action be taken in the near-term to begin reducing emissions in key emitting countries, including those such as the United States and Australia, which have not ratified Kyoto, and large developing economies that are not required by Kyoto to reduce emissions. These actions would involve voluntary partnerships designed to find win-win solutions. The overall strategy should be focused on developing lowcarbon or no-carbon energy sources, including renewable energy, and increasing energy efficiency. As part of that strategy, agreements at the sub-global level among significant emitters can address specific emissions and technology development challenges that complement existing climate change regimes.

Reforms at the national level would include: Leveling the playing field between renewable and fossil fuels, and internalizing the latter's costs by phasing out fossil fuel subsidies and adopting cap and trade systems as well as encouraging ecological tax reform and performance based efficiency incentives. Use of innovative government-supported financial mechanisms, such as clean energy funds and government-guaranteed investment securities ('global development bonds') that would promote investment in sustainable low- or nocarbon technology deployment. Providing new support for low or no-carbon technology transfer to developing countries in addition to existing bilateral and multilateral programmes, including by increasing the provision of concessional finance.

Reforms at the international level would include: Reviewing and significantly increasing the World Bank target to increase its investment in renewable energy, arising from the extractive Industries Review. Reforming the OECD Arrangement for ECAs to improve the terms offered by ECAs for renewable energy and energy efficiency projects so that they are at least as favorable as those for fossil fuel and nuclear energy. Requiring multilateral banks to take the climate impact of their project financing into account by conducting energy audits on energy-intensive projects and financing energy-saving measures, following the lead of the European Bank for Reconstruction and Development, and to adopt minimum efficiency standards for the projects they support or portfolio-wide carbon intensity standards. ${ }^{5}$

\section{Sustainable Development}

\section{Possible Position}

Development is usually defined principally in terms of economic growth. The familiar indicator is gross national product. Limitations of the Gross National Product (GNP) are: not inclusive. It does not include household activities and Informal sectors. There are many ways to define sustainable development. As Ecological systems and agricultural development: the world conservation strategy argued that the maintenance of ecological processes could only be brought about if urgent consideration were given to three specific conservation objectives: the utilsation of good cropland, the ecologically sound management of crops and the protection of watershed forests. As Energy efficiency and agriculture development: the search for more sustainable development necessarily involves two interrelated dimensions. First we need to consider to what extent we use energy efficiently within agriculture at the present time. Second, we need to consider population, together with ecological sustainability and energy efficiency. As Population growth and carrying capacity: rapid population growth in poor countries.

The term sustainable development was used at the time of Cocoyoc declaration on environment and development in the early 1970s. The term has catalyzed the debate over the relationship between economic change and the natural resource. The term suggests that the lessons of ecology should be applied to economic processes. It encompasses the idea in the world conservation strategy, providing an environmental rationale through which the claims of development to improve the quality of life can be challenged and tested. ${ }^{6}$ Sustainable development is an ambiguous concept. It covers government policy, business strategy and lifestyle decision. The phrase has been continually refined to cover wider issues. It has become a complex

\footnotetext{
4. A.N. Sarkar, Global climate change: beyond copenhagen, (New York: Pentagon Earth, 2008).

5. Stephen Byers and Olympia Snowe, Meeting the Climate Change: Recommendation of International Climate Change Task Force (London. Public Policy Research, 2005).

6. Redcliff Michael, Sustainable development- exploring the contradictions(London and New York: Rutledge,1987).
} 
interdisciplinary subject providing an interesting case of the constraints and pitfalls in modern living. Brundtland (1987) report define it as a development that meets the needs of the present without compromising the ability of future generations to meet their own needs. National Strategies for sustainable development (2000) define it is economic and social development that meets the needs of the present without compromising the ability of future generations to meet their own needs. World Wildlife Fund defines it as improving the quality of life while living within the carrying capacity of supporting systems. What is sustainable business practice? World Business council for sustainable Development (2001) Sustainable Development practices requires business leadership as a catalyst for change toward sustainable development and to promote the role of ecoefficiency, innovation, and corporate social responsibility toward sustainable development. What is sustainable city? A sustainable city is organized so as to enable its citizens to meet their own needs and to enhance their well- being without damaging the natural world growth and the future. ${ }^{7}$

Sustainable development is a huge and complex challenge at least in ethical terms. The nature of this ethical challenge may be summarized in terms of the three types of obligation to which sustainable development relates: towards people who are already living, towards people who are not yet born and towards species other than humans. Given three such different types of obligations, individuals and groups are often faced with a serious moral dilemma. The central idea of a moral gradient is that the extent of one's moral obligations to others is not absolute but instead varies according to what can be considered one's moral distance from others. The further away the other is perceived to be, the less is the extent of one's obligation to them. Moral distance refers to three different dimensions of distance; three different ways in which other beings may differ from oneself in ways that are morally significant. First, there is the distance between one person and other people alive at the same time what might be called social distance. Second, there is the distance between one person and others who do not yet exist what might be called temporal distance. Third is the distance between a human being and other species that inhabit the globe: animals, plants, etc. This might be called species distance. It seems to be widely held that the extent of one's moral obligation declines with moral distance along each of these dimensions. Thus, for example, a person's obligation to another human being may be considered greater than his/her obligation to a dog. The moral gradient is by no means a smooth gradient, varying uniformly with each of the three moral distances. ${ }^{8}$

Collective-action problems occur when it takes the inputs and efforts of multiple individuals in order to achieve joint outcomes and it is difficult to exclude beneficiaries of these actions from benefiting even if they do not contribute. Collective-action problems vary in scale from very small problems involving only a few individuals to extremely large problems involving global resources, such as the atmosphere and the oceans. Solving collective-action problems requires opening public and private spheres of activities ranging from the small to the very large so as to encourage effective problem solving. If we are to solve collective-action problems effectively, we must rethink the way we approach market and governmental institutions. Analytical approaches that are consistent with a public sector encourage human development at local, regional, national and international levels are required. Diverse interests motivate public entrepreneurs including improving services to their own communities, sharing the burden for increasing benefits, the stimulus of innovation, the respect they receive from others, as well as the income they derive from their positions in public service for those who are not entirely volunteer workers. ${ }^{9}$

There are three areas of debate in the Sustainable development- the equality- inequality theories, the techno-centered theories and theories of balance. The fundamental belief across first area of debate is that humanity is the centre of the debate. The debate probably includes positions across transformation, reform and status quo. Much of the debate is primarily concerned with the human side of sustainable development, with one view being that happy thoughtful humans look after their environment. The reformer sees the current system as fundamentally flawed and promoting more rather than less inequality. They see the manifestation of problems arising from the inequality, and many would argue that poverty and most environmental problems arise from poorly managed capitalism. Income inequality has led to the link between left- leaning politics and green politics. NGO's have become an important element of the sustainable development debate and it is believed that there are atleast 30,000 international NGOs in existence. Greenpeace is an example of this. Originally a body that probably sat close to the deep green claiming devotion to nature above materialism or greed, it has now been described as a corporation. Many environmentalists see social issue as equally important in the debate. Many would see a link between environmental crisis and social one. One belief is that people having control over their lives, resources and environment reduces inequality and environmental degradation.

7. Mark Mawhinney, Sustainable development: understanding the green debates (UK: Blackwell, 2002).

8. Mcneill Desmond, Ethics, politics, economics and global environment, in Karen O Brien (Ed), Climate change, ethics and human security, ( U.K: Cambridge,2010).

9. Ostrom Elinor, Polycentric systems as one approach to solving collective action problem, in M.A Mohammed Salih (Ed.), Climate change and sustainable development- new challenges for poverty reduction,(U.K: Edward Elgar,2009). 
Ecofeminists proposed a link between the subordination of women and degradation of the environment. Ecosocialist see the cause of environment degradation in the economic structure of capitalism. Many bodies such as the world bank, the EU and national government now encourage a belief in the concepts of social and environmental capital along with the economic capital. Puttnam points that a decline in the communal behavior in the USA as being a strong marker of the loss of social capital. Technocentric arguments is the domain of scientists and technologists. This school of thought deals with Factor 4 and Factor 10 types of arguments. The factor 4 theories concentrated on resource efficiency but acknowledge the need for new tools for measuring business efficiency, innovations in business practice and some changes to public policy. The factor 10 theory added cultural facto and address the restoration of natural capital. A factor 4 theory promotes a market- led approach adapting and setting new markets to improve the situation but maintaining the status quo. Facto 10 introduces the reform school, where reform beyond markets is more identified. The theories of balance demands balance between economic, environmental and social needs. It includes Brundtland Commission, Green Consumerism and the European Commission. ${ }^{10}$

\section{Resource Conservation}

Although the idea of conservation, in the sense of the "prudent husbanding" of nature's bounty, can be traced back as far as Plato, Mencius, Cicero, and the Old and New Testaments, its twentieth-century scientific and utilitarian manifestation is intricately bound up with the rise of modern science from the sixteenth century. Those who have inquired into the historical roots of the modern conservation doctrine have generally traced its popularization in North America to Gifford Pinchot, the first chief of the United States Forest Service, described by Devall as the prototype figure in the conservation movement. Central to Pinchot's notion of conservation was the elimination of waste, an idea that the environmental historian Samuel P.Hays has dubbed the gospel of efficiency, which he sees as lying at the heart of the doctrine of conservation. ${ }^{11}$

The basic thrust of the Resource Conservation standpoint was to restrain the reckless exploitation of forests, soils, etc., characteristic of the pioneer stage of modern social development by imposing ethical and legal requirements that natural resources be used wisely, meaning (in Gifford Pinchot's words)that they should be used "for the greatest good of the greatest number" (of humans), as distinct from being used to profit a few, and that the good should be considered in "the long run," that is, in terms of a sustainable society. Resource conservation also includes Wilderness preservation, Moral extensionism, Ecological sensitivity. Wilderness Preservation tradition, represented in part by Fohn Muir and the Sierra Club, was also emerging a social force. Moral extensionism designates a wide range of positions whose common characteristic is that they contend that humans have duties not only concerning but also directly to nonhuman natural entities and these duties derive from rights possessed by the natural entities, and that these rights are grounded in the possession by the natural entities of an intrinsically valuable quality such as intelligence, sentience, or consciousness. Ecological sensitivity consists of three major components of it- a theory of value that recognizes intrinsic value in nature without engaging in mere extensionism; a metaphysics that takes account of the reality and importance of relationships and systems as well as of individuals; and an ethics that includes such duties as noninterference with natural processes, resistance to human acts and policies that violate the noninterference principle, limited intervention to repair environmental damage in extreme circumstances, and a style of co-inhabitation that involves the knowledgeable, respectful, and restrained use of nature. ${ }^{12}$

\section{Green Economy}

It represents the ecological wing of mainstream economics; it speaks with an authoritative and technical voice to the entirety of economic relations with nature. Ecological economics are not interested in social transformation and accept the potentials of the present system to absorb the crisis. It means ecological economists employ a great variety of instrumental measures like incentive based regulations, ecological tariffs and natural capital depletion taxes, penalties to the polluters. There are several schools of thought on the relationship between the environment and economic growth. They range from what O' Riordan has termed the environmental moralists who deny that the environment is a commodity at all to those who argue that environmental goods should be treated exactly like any other commodity. Economists like Pearce argue that it is possible to consider the environment within the governing economic paradigm, and that the field of bioeconomic has already made substantial progress ${ }^{13}$.

10. Mark Mawhinney, Sustainable development- understanding the green debates, (U.K: Blackwell, 2002).

11. Robyn Eckersley, Environmentalism and political Theory-towards an ecocentric approach (London: UCL Press,1992)

12. John Rodman, Four forms of ecological consciousness reconsidered, in George Sessions (Ed), Deep Ecology for the TwentyFirst Century, (U.S.A: Shambhala Publication, 1995).

13.

Redcliff Michael, Sustainable development- exploring the contradictions (London and New York: Rutledge, 1987). 
Environmental economists start from the assumption that a good deal of economic activity today is unecological which requires serious reforms. Environmental economists did not consider it necessary to radically redefine the scope of economics. In both theory and practice it is managing the scarcity. Its prime concern is the allocation of scarce resources to alternative ends. Thus what environmental economics aims to do is to bring the economic conception more in line with the ecological values. The human values assumed by modern economics are predominantly those of individualistic and materialistic hedonism. The good life amounts to little more than the fulfillment of the immediate interests of those with something to buy or sell on the market. These values sustain the quantitative assumption of economics but not the qualitative. Environmental economics differs from conventional economics in that it does not uncritically accept the assumption that growth is an end in itself. The radical approach attempt to redefine human development in primarily ecological, as opposed to economic terms. ${ }^{14}$

The approach of the Ecosystem involves the restructuring of economy which demands Green market economy. The ecological measures proposed by the Greens flow from their rejection of purely quantitative growth. The Greens demand the dismantling of life-threatening industries, above all the nuclear and weapons industries, and the reorientation of production towards ecologically benign and socially necessary products. One of their slogans is 'No investments without a future! 'They propose a number of specific ecological investments in the area of energy production, recycling, water management, agriculture, housing, and traffic. Economic decentralization, utilization of existing local resources, and judicious use and recycling of raw materials are the outstanding characteristics of these ecological investments. Another significant feature of Green economic policy is its revaluation of North-South relations. The Greens demand an orientation towards a self-reliant internal economy, rather than exploitation of the Third World, and they declare their solidarity with Third World countries in their efforts to lessen their dependence on the northern hemisphere. A grassroots democratic economy, finally, according to the Greens, is one that allows for self-managed, cooperative enterprises in which those involved in the production process are able to decide themselves what is produced, as well as how and where it is produced. The ecological economy envisaged demands the partnership between humans and nature.

The Green economic programme contains the following concrete proposals for ecologically meaningful investments. Energy production: Conservation measures should be designed and encouraged; soft production modes of energy should be developed; energy regulations, which now permit the establishment of monopolies, have to be modified. Recycling: Production generating waste that is not safely disposable must be outlawed; new recycling. techniques have to be developed. Water management: Biological water treatment processes should be expanded; closed water systems for industrial production and cooling should be mandatory; the self purification capacities of rivers must be supported by ecological means. Agriculture: Ecological agriculture should be promoted and developed on decentralized self-reliant farms; rural areas must be revitalized and regional administrative structures improved. Housing: A radical reorientation of housing policies and restructuring of financial instruments to support housing construction will be necessary; the decisions about financing have to be transferred from the federal to the community level; land prices have to be controlled and financing has to be uncoupled from the real estate market by direct use of public money. Traffic: Public transportation is to be increased together with a substantial reduction of fares; car traffic has to be restricted while pedestrian and bicycle traffic is encouraged and facilitated; all further construction of freeways and airports must stop. The Greens' deep ecological awareness is evident from their detailed and often very beautiful formulations of these proposals. The restructuring of the economy envisaged by the greens involves not only a redefinition of work but also of private property. ${ }^{15}$

A more feasible alternative might be to draw back from the idea of a predominantly planned economy in favor of the idea of a greater range of macroeconomic controls on market activity that are designed to ensure that market activity remain subservient to social and ecological considerations. Here, the emphasis would be more on managing, containing, and disciplining rather than largely replacing the market economy, although some economic planning would still have a role to play. Although both ecosocialists and Green economists enlist the values of participatory democracy, ecological responsibility, social justice, decentralization, and the dispersal of economic and political power, they differ over how these values are to be interpreted and applied. Whereas ecosocialists tend to emphasize the evils of the market economy and seek to democratize and ecologize State and local economic planning institutions, Green economists tend to emphasize the evils of central planning and seek to democratize and ecologize the institutions of the market economy. Although Green economists are trenchant critics of corporate capitalism, they are equally critical of the concentration of economic power in the hands of the State. Accordingly, Green economists have tended to place greater emphasis on the need to develop

14. Tim Hayward, Ecological thought-an introduction, (U.K: Polity Press, 1995).

15. Charlene Spretnak and, Fritjof Capra, Green politics- the gobal promise (London: Paladin Graflon Books, 1985). 
small business, local cooperatives, and local economic self-reliance. Nonetheless, they also advocate increasing government economic management through transformed-market conforming planning, that is, new institutional, fiscal, monetary, and pricing policies designed to ensure that the market has as intrinsic tendency to move in directions that conform with the society's social and environmental goals. Rather than seeking a predominantly planned economy (with a small private sector).

Green economists seek to bend and stretch the historically given conditions currently prevailing. In other words, they envisage a market economy with a reasonably large private sector. Most Green economists have tackled the problem of scale (i.e., the protection of ecological carrying capacity) by advocating (i) a range of new fiscal measures (such as resource depletion quotas and higher resource taxes and pollution charges) designed to control resource depletion and reduce material-energy throughput (ii) more comprehensive, and longer-range, environmental impact assessment and technology assessment and (iii) the replacement of indiscriminate GDP statistics with an alternative index of economic progress designed to provide a more meaningful yardstick by which to measure economic well-being. ${ }^{16}$ Economics itself has almost become an ideology; the ideology of unlimited material progress within a limited time perspective. This form of progress involves increasing specialization in production and decision-making, based on a continuous drive towards bettering material conditions. The ideology of economic growth guides decisions regarding the use of scarce resources and the quality of our physical environment. Additionally aggregate economic expansion is still supposed to offer solutions to a broad spectrum of social problems. Since it equates value with pecuniary market price and progress with increasing material production and consumption, economics has come under attack from environmentalists. Economic growth in the usual terms of Gross Domestic Product (GDP) per capita simply implies an increase in aggregate production. In calculating GDP, usually there is no price attached to nature. This way of calculating progress affects our society in many ways. It dominates policies regarding production, income and the use of resources. One resulting fallacy is the belief that in order to sustain the environment, a lot of money must first come through economic growth. This is a modern macroeconomic paradox. For an individual enterprise, it is true that the money needed for cleaning polluted air, water and soil has to come from earnings (profit), which normally implies growth. However what is true at the micro level is not necessarily valid at a (national or international) macro level. Aggregate growth of production at a macro level means more depletion of resources, more waste and more pollution. Daly Opschoor argued that natural capital should be maintained, but not necessarily in the sense that the ecosystem is not affected by human behavior. ${ }^{17}$

Markets, no matter how well cleaned and informed, cannot adequately ensure environmental protection. Besides market stimuli, this requires utilizing legal and institutional incentives in the form of juridical and administrative regulations. This requires permits, licenses and bureaucratic procedures. A first requirement for a successful institutional response is a strong state. A second condition for effective regulation is that legal systems must function adequately. The review of the UN Conference on the Human development recommended the creation of a World Commission on Environment and Development. The Commission recognized that earlier global environmental initiatives had suffered for lack of funding. The idea of a green financial instrument seems to have been promoted in the mid 1980s by a banker, Michael Sweatman. Global environment facility was to provide additional, concessional grant finance to meet the incremental costs of creating global environment benefits, support activities that benefit the global environment in four focal areas: climate change, biodiversity, international waters and ozone depletion. It fund activities that are country-driven and fit with national policies for sustainable development, operate through Implementing Agencies (World Bank, UNDP and UNEP). ${ }^{18}$

\section{Trade and Travel}

Trade is viewed with suspicion by greens on four grounds. In the first place it is a site of the exercise of political and economic power and an easy way to exchange self-determination for dependence; second, it encourages frippery and helps to turn wants into needs third, patterns of trade end up being notoriously wasteful of resources and fourth, reliance on one or two products for export can render economies vulnerable to a drop in prices or a general worsening of the terms of trade. As a result of these views on trade, green economic practice would be built substantially around protectionism: it's clear that selective protection of the domestic economy will be needed to establish its sustainable basis, and to encourage the country to become far more self-sufficient than it is at present. One of the characteristics of the radical green sustainable society is that people would travel less. Arne Naess in his 1987 Schumacher Lecture referred to the principle of 'limited mobility', and William Ophuls, too, believes that personal mobility would be limited in such a society. In the first place, this is because

16. Robyn Eckersley, Environmentalism and political Theory-towards an ecocentric approach (London: UCL Press,1992).

17. Elinor Ostrom, Polycentric systems as one approach to solving collective action problem, in M.A Mohammed Salih, (Ed.), Climate Change and Sustainable Development- New Challenges for Poverty Reduction (UK: Edward Elgar, 2009).

18. Young Zoe, A new green order? the world bank and the politics of the global enviornmental facility, (London: Pluto Press,2002).

$\begin{array}{ll}\text { www.iosrjournals.org } & 89 \mid \text { Page }\end{array}$


greens consider present travel practices to be wasteful of resources. The ecological footprint associated with air travel is an increasing worry, even for mainstream politics, as the climate change emissions associated with air travel increase at a faster rate than any other sector of the economy. Second, and more importantly, greens argue for reduced mobility as a part of their hopes reliant communities. From this point of view travel involves dislocation of the ties for generating supportive, satisfying relationships in their decentralized, self- that hold such communities together, and so endangers the emergence of the sense of loyalty and involvement that, for greens, will be one of the prime benefits of decentralized communitarian life. The sustainable society is substantially about living in place and developing an intimacy with it and the people who live there; travel, on this reading, is too expansive and too centrifugal an occupation.

\section{Bioregionalism}

This doctrine connects some of the principle of community economics. Bioregionalism represents a specifically ecological rendition of the contemporary movement toward the break up of nation-states. It differs from the separatists on the ground that they demand the ecological preconditions of nationhood. This is not merely a location but the concrete ecological workings of a part of the earth: the flows of watersheds, kinds of soils, the biota that inhabit a bioregion. From this perspective, the bioregion is essential ground within which the principle of sustainability and its reliance on ecological technology and economics may be applied. The problem is who is to decide who live where? ${ }^{19}$ Kirkpatrick Sale simply expressed the bioregional paradigm: "We must get to know the land around us, learn its lore and its potential, and live with it and not against it. We must see that living with the land means living in, and according to the ways and rhythms of, its natural regions - its bioregions". Living bioregionally involves identifying bioregional boundaries and living (for the most part) with what those territories provide in the way of, for example, 'given ores and minerals, woods and leathers, cloths and yarns. The bioregional community would seek to 'minimize resource-use, emphasize conservation and recycling and avoid pollution and waste' (Sale, 1984, p. 230), and all of this would be aimed at achieving sustainability through what Sale calls self-sufficiency. Bioregionalists will usually insist that land be communally owned because the fruits of nature are fruits for everyone, and they will urge that polities follow the natural world's example and abhor systems of centralized control. Consequently, they advocate 'the spreading of power to small and widely dispersed units' (Sale, 1985, p. 91). Associated with this is the idea that nature's lesson as far as social relations are concerned is one of equality, or what Sale calls complementarity. The guiding principle of bioregionalism, then, is that the natural world should determine the political, economic and social life of communities.

\section{Market Based Instruments}

The aim of market based instrument (MBIs) is to prevent market failure by applying the polluter pays principle. A market-based instrument internalizes into the price of a good or product the external costs to the environment of producing and using it. Market based instruments involves : Eco-taxes- user charges, fees payable for treatment, collection and disposal costs of wastes or other environmental administration, emission charges, charges on the discharge of pollutants into air, water or soil (i.e. directly linked to quantity and quality of pollutant), e.g. taxes on sulphur emissions and Product charges, charges on harmful products, e.g. fertilizers and tradable permits. ${ }^{20}$

\section{Energy Policy}

If reduced consumption rather than more technological devices is the answer to the problems raised by the absolute scarcity of resources, then greens will point out that the same must apply to the use of energy. Energy is, of course, a resource, and, to the extent that current global energy policies rely principally on nonrenewable sources of energy, is also a limited resource. Nuclear power itself is produced from the limited resource of uranium and so seems unlikely to solve the problems brought about by resource scarcity. At the same time, while actual resource levels may be quite high, available non-renewable energy resource levels will be somewhat lower. In the face of the perceived disadvantages of relying for energy on limited stocks of polluting and dangerous non-renewable resources, greens usually base their energy strategy around renewable sources of energy, the conservation of energy, and reduced consumption, of both energy and the durable objects that it helps us produce. However green suspects technological solution and they assert that true solution lies in reducing the consumption of energy. ${ }^{21}$

Sustainable energy strategies must address both the supply and demand sides of the energy equation: electricity generation must shift away from a dependency on fossil fuels, notably coal and oil, towards

19. Joel Kovel, The enemy of nature- the end of capitalism or the end of the world?(London: Zed Books, 2002).

20. Neil Carter, The Politics of the environment-ideas. activism. policy, (U.K: Cambridge,2007).

21. Andrew Dobson, Green political thoughts (London and New York: Rutledge,2007). 
renewable energy sources such as hydroelectric power (HEP), wind, solar, wave and biomass, which emit low or zero carbon; energy consumption must be reduced in both industrial and domestic sectors through improved energy efficiency and conservation measures. To date, little significant progress has been made towards sustainability in either the generation or consumption of electricity. On the supply side, few countries boast a large renewable energy sector. So the development of alternative renewable sources is essential. Yet several serious obstacles make this a challenging policy goal, including powerful energy producers, competitive liberalised energy markets, discriminatory fossil fuel subsidies and technological problems. Wind is the largest renewable energy source after HEP. The total global capacity for generating electricity through wind power was about $59.4 \mathrm{GW}$ in 2005. It is unlikely that renewable energy will become a significant source of electricity generation without the imposition of a carbon tax on fossil fuels that is set sufficiently high to make the fledgling renewable sector more competitive. There are numerous ways of improving domestic and industrial energy efficiency. Some governments have set high mandatory energy efficiency standards for buildings, subsidized home conservation and low-energy light bulbs, and agreed energy efficiency classification systems for consumer goods such as washing machines.

\section{Transport Policy}

Transport policies in most countries have traditionally adopted a 'predict and provide' approach to the expansion of road and air transport: predict the anticipated growth in each sector and provide the roads and airports necessary to support it. Some governments, notably in the USA and Canada and the Thatcher government in the UK adopted a pro-roads stance with particular ideological fervour, directly linking road construction to economic growth and freedom of the individual. By 2000, global passenger car production reached 40.9 million vehicles, contributing to a global total of around 532 million vehicles, with the annual distance travelled by each driver rising steadily. Climate change prevention requires a fundamentally different approach to transport policy. A sustainable transport policy has to address both supply and demand. On the supply side, air and road transport need to produce fewer polluting emissions; on the demand side, traffic volume must be reduced so that fewer journeys are made by car and plane. Policymakers have pinned their hopes on the supply-side objective of developing greener motor vehicles. In recent years, several major vehicle manufacturers have launched new models that use biomass products, such as ethanol and methanol, or liquefied petroleum gas or run on electricity. They are also working with oil companies, such as BP, to develop alternatives, such as hydrogen fuel-cell technology. ${ }^{22}$

The transport sector accounts for approximately one third of global greenhouse gas emissions. While increased investment in public transportation systems is one important strategy to reduce emissions in this sector, these emissions can also be greatly reduced through improvements in fuel efficiency. For example, hybrid gasoline/electric cars can cut fuel use by one-third. Governments could also commit to providing tax incentives for retooling manufacturing plants, and to replacing their own fleet vehicles with HEVs, thus boosting demand and reducing the costs of production and the price gap between HEVs and conventional vehicles. Transport-related emissions can also be reduced by switching away from fossil fuels and towards renewable energy sources such as biofuels, especially those derived from cellulosic materials, which can be blended with petroleum based fuels. Appropriate safeguards would need to be adopted to ensure that increased subsidies for biofuels encourage sustainable farming methods, preserve culturally and ecologically sensitive land, and protect biodiversity. ${ }^{23}$

\section{Live With Less}

Most environmental problems are ultimately due to our voracious demand for new things. Making all those new cars, gadgets, clothes and so on eats up raw materials and energy. Instead, learn to reduce, reuse, recycle in that order. Reducing -living with less - is the best and simplest solution. Where you can't do without, reuse things by repairing, adapting, swapping, borrowing, buying second-hand, etc. And if you can't reuse something, recycle it - that way, no new raw materials have to be grown or extracted. Don't forget to buy recycled products to complete the recycling loop. Reduce energy, water, chemicals, waste. Being green means using less fossil-fuel energy, water and chemicals and creating less waste. Green alternatives: something is green if it is natural, reusable, renewable, locally produced, Energy/water-efficient and nonpolluting. Of course,

\footnotetext{
22. Neil Carter, The Politics of the environment- ideas. activism. policy, (U.K: Cambridge,2007).

23. Stephen Byers and Olympia Snowe, Meeting the Climate Change: Recommendation of International Climate Change Task Force (London. Public Policy Research, 2005).
} 
often you have to use your judgment to make choices (such as between imported organic and local nonorganic food or perhaps you could find an alternative that is both local and organic. ${ }^{24}$

\section{Voluntarism}

A good intention, desire to recycle waste, or work in a community garden, connection to special movements, conscious of ecological crisis. Thus voluntarism is an action taken by an individual on moral ground. i.e work to control the environment. However admirable individual acts of charity or ecological sanity may be, they tend either to be co-opted, or to remain merely local and lose the thread of effective collective action. ${ }^{25}$ Voluntary action involves individuals or organizations doing things to protect the environment that are neither required by law nor encouraged by financial incentive. Voluntary action is the main way in which individuals, by changing their lifestyles and acting as ecological citizens, can contribute to the achievement of a more sustainable society. Individuals can engage in a wide range of voluntary activities, including green consumerism, ethical investment, recycling and voluntary conservation work. The government can encourage voluntary action through a range of communicative strategies such as information campaigns setting out the environmental benefits of recycling drink containers or newspapers, extending citizen rights to environmental information and making it easier for individuals and organizations to take polluters to court.

Businesses may also choose Eco-Management and Audit Schemes (EMAS), environmental management standards such as ISO 14001 and eco-labeling. Voluntary agreements may generate constructive co-operation between the state and industry along the lines of ecological modernization, leading to changes in the environmental values and behavior of both state officials and producers. Nevertheless, voluntary agreements have their weaknesses too. Their environmental effectiveness is questionable and their economic efficiency is low. They are often unambitious, involving commitments at the level of the lowest common denominator acceptable to the least enthusiastic signatories to the agreement. An industry will often only establish a voluntary agreement as a means of forestalling the threat of a tougher regulation or eco-tax. Also there are certain steps to make our home green like insulating your loft and wall cavities. Lag your boiler. Fit draft excluders to doors/windows, fit thermostatic valves to each radiator so you can turn off those in rooms you're not using, then shut doors and just heat rooms you are using. Turn heating down and wear warm clothes instead - it can cut heating bills by ten percent. Set central heating to go off at night, when you go to work and when you go on holiday, take short showers (not baths). Fit a water-saving showerhead. Ensure electric boilers have a timer to heat water only when needed, fit energy-saving light bulbs, Turn lights off when you leave the room, Maximizing light output from each bulb means you can light your home using fewer lights so clean lampshades and light bulbs, as dirt can cut light by fifty per cent. Silver reflector strips behind light bulbs will also help increase effective light output, turn appliances off at the wall. Standby mode can use almost as much energy as leaving things on and can account for 10 per cent of your electricity bill, use cold water or wash at 30-400C. Dry them on a line or airer instead of in a tumble dryer. ${ }^{26}$

\section{Lifestyles}

The general principle behind both lifestyle and community strategies is that changes of consciousness and changes in behavior are mutually reinforcing. Lifestyle change concerns changes in the patterns of individual behavior in daily life. Typical examples of this would be: care with the things you buy, the things you say, where you invest your money, the way you treat people, the transport you use and so on. Recently there has been a veritable explosion in the popularity of green lifestyle changes in Britain. Home ecology, among certain sections of the community at least, is all the rage. Retailers have picked up and reinforced this trend, and the major supermarket chains fall over themselves to stock their shelves -a few of them anyway -with environmentally friendly goods. Products in green packets sell significantly better than similar products packaged in any other colour. In this context, green has rapidly become the colour of capitalist energy and enterprise. The theme is that personal transformation leads to altered behaviour; which in turn can be translated into sustainable community living: The only possible building blocks of a Greener future are individuals moving towards a Greener way of life themselves and joining together with others who are doing the same. The positive aspect of this strategy is that some individuals do indeed end up living sounder, more ecological lives. More bottles and newspapers are recycled, more lead-free petrol is bought, and fewer harmful detergents are washed down the plughole. Greens often speak of change of consciousness is to bring about radical shifts in social and political life. ${ }^{27}$

\footnotetext{
24. Mark Mann, Its easy being green, (U.K: Summersdale Publishers, 2007).

25. Joel Kovel, The enemy of nature- the end of capitalism or the end of the world?(London: Zed Books, 2002).

26. Mark Mann, Its easy being green, (U.K: Summersdale Publishers, 2007).

27. Andrew Dobson, Green political thoughts (London and New York: Rutledge,2007).
} 
Avoid wastage- the best way to avoid waste is to buy less stuff, use those things which can be reused; keep plastic bags away, use your recycling bins, drive less and use public transport, car pool with colleagues or neighbours, use cycle or electric scooter, reduce car trips and make your car fuel efficient, learn fuel efficient driving, support campaign for better public transport and cycle networks, buy fewer new clothes, learn to use second and repair the clothes, use few cosmetics, support a green organization and work for it such as Friends of the Earth, WWF or Greenpeace, vote for politicians you think will put the environment first, join a local green group, project or campaign. As one of the reason of environmental degradation is population, one should adopt family planning and support population control policy. Poverty is also one of the reason of environmental degradation; thus one should focused on poor and work for uplifting them. ${ }^{28}$

\section{Fiscal Incentives and Ecological Citizenship}

An increasingly popular way of trying to get people to behave in more sustainable ways is to arrange taxes, charges and benefits in such a way as to encourage them to do so. One example of this is the congestion charges that have sprung up in various cities in Europe and elsewhere. Car drivers in these cities are charged to enter designated zones at certain times of the day, and the hope is that they will be deterred from doing so and use alternative forms of transport instead. Another example is the tax on plastic shopping bags that the Irish government instituted in 2002. Here the idea was to deter people from using new bags each time they went shopping, and to encourage the reuse of bags.

Environmental citizenship borrows the idea of transnational citizenship from the cosmopolitan tradition. Thus environmental citizenship speaks the language of obligation, of the common good and of the global reach of citizenship relations. In these respects it takes a rather different view of human motivation to the fiscal incentive strategy. It recognizes (or assumes) that people sometimes act in order to 'do good' as well as to try to ensure some gain for themselves. One of its central ideas is that of the equal right to environmental space for all citizens - that is to say, everyone in the world. Given that environmental space is currently very unevenly shared out, environmental citizens will work towards the redistribution of environmental space - reducing the size of their environmental footprints where appropriate. Thus the environmental citizen is motivated to live sustainably because it is just to do so, not because she or he is prompted to do so by fiscal incentives or disincentives. ${ }^{29}$

\section{Spiritual Approach}

Spirituality is of greater importance to the green perspective than is probably publicly realized, and this has made a significant impression on some activists in the movement with regard to how change might come about. The general point behind the spiritual approach is that the changes which need to take place are too profound to be dealt with solely in the political arena, and that the psyche is as important as the parliamentary chamber. Jonathon Porritt writes that 'for sustainable development . . . a spiritually inspired work ethic will be an important instrument of change'. Marilyn Ferguson has recommended the use of 'psychotechnologies' to bring about calmer, gentler, more 'green' states of consciousness. Rites as a mean for saving the planet from the environmental destruction. Rituals has environmental significance.

Ecological restorationists such as Wlliam Jordan III attempted to show the pragmatic actions of rituals such as prairie burnings that restore the degraded environments. Australian John Seed has developed an event called the council of all beings. He and Ruth Rosenhek lead a series of re-earthing rituals and workshops, some of which include a welcoming of species and an honouring of local indigenous people, as well as mourning and bonding exercises. They believe that people will act morally and politically if they experience the depth of their own planetary despair and cultivate a felt connection with the earth and its creatures. In a culminating phase of one event, participants arrive masked as animal allies. When the event concludes, folk take off their animal selves and assume their usual, human masks, thereby learning that human is just one among many masks that animals wear. A few mainline religions too have begun constructing environmentally oriented rites. Buddhist monks in Thailand, for instance, are ordaining trees, thereby making them into Buddha and forcing land clearer to have conscience towards nature. Artists too are working in concert with some of these movements. Canadian composer Murray Schafer has been engaged in what he calls theatre of confluence. In wooded rural areas, a series of ritualized musical performance rites called Patria (homeland) began in 1966 and continues today. ${ }^{30}$ In the old testament we are given the injunction: thou shalt not muzzle the ox when he treadth out the corn." It indicates minimal welfare to animals. in Gensis(2:15) we were instructed to dress the garden and keep it. George Berkeley, eighteenth-century bishop and empiricist philosopher maintained that the world is not only organized

28. Mark Mann, Its easy being green, (U.K: Summersdale Publishers, 2007).

29. Mark Mann, Its easy being green, (U.K: Summersdale Publishers, 2007)

30. Ronald Grimes, Ritual theory and environment, in Bronislaw Szerszynski, Wallace Heim and Claire Waterton (Ed), Nature performed: environment, culture and performance (U.K: Blackwell, 2003). 
for our benefit, but is an integrated system of signs for our instruction. According to such views the lion and Ox is a resource for the ultimate benefit of humankind. Generally there is a despotic position of morality to human beings. 31

\section{Acton Through Legislature}

Many countries have green parties that seek election to national legislatures. Green movements in all countries that have them see it as at least part of their role to try to influence the legislative process, while policy is being drawn up, while bills are being debated, or during their execution. The principal assumption behind both kinds of activity is that the liberal-democratic decision-making process and the economic structures with which it is engaged are sufficiently open to allow the green agenda to be fulfilled through them. It seems to be accepted that even if a green party is not elected to government, then sufficient pressure may be brought to bear on the incumbents to bring about a sustainable society. Until the early 1980s there were no Green Party members of Parliament anywhere, and certainly no green parties anywhere near government. Now that has changed. At the time of writing (June 2006), European green parties boast one hundred ninety two seats in national parliaments, with two ministers in government (in Italy and Latvia). And until the last election changed the panorama of German politics, the Green Party played a major role in government there, with Green Party member Joschka Fischer holding the key portfolio of Foreign Minister. Thus greens have tasted electoral success within the constraints of the liberal-democratic framework. ${ }^{32}$

There is no unified vision of green democracy. Nevertheless, we can set out two sorts of vision- the authoritarian and communitarian direct democracy. The most outrageous authoritarianism comes from extremist groups like the American Earth First. Beyond these extremes, the work of Ophuls who deals explicitly at length with ecological political theory can be taken as a clear example of authoritarian tendencies. He has suggested that with the return to scarcity we must question whether democracy as we know it can survive.He suggests a return to competence, or what Dahl calls guardianship. Most visions of green democracy are, however, variants on a model of direct democracy in small, often rural, face-to-face communities, characterized by labour intensive production, self-reliance if not self-sufficiency, a related minimization of trade and travel between communities, and decision-making by face-to-face assemblies along the lines of the Athenian assembly.

For Bookchin, the emphasis is on public talk and public spaces in the decentralized communities, breaking down distinctions between politics and administration, and the need for empowerment of people through participation, involvement, and a sense of citizenship that stresses activity, not on the delegation of power and spectatorial politics.Sale gives priority to 'bioregional' organization of communities over direct or other forms of democracy. The elements of Green democracy are: stress on small decentralized communities, face-to-face assemblies and proximate forms of participation and accountability, rotation of representatives and a strong emphasis on equality of input from all community members. The alternative vision of direct Green democracy is semi- direct democracy which enhances technologies for voting, consultation, conferencing, and so on. Less sober accounts see direct voting via television referenda as completely cutting out intermediaries and giving power back to the people: Toffler's view was that 'Public opinion will become the law of the land'. More sober accounts stress a variety of 'teledemocracy' schemes and a number of problems, such as access, agendasetting and citizen apathy, associated differentially with each of them.

The second revision of the green vision of direct democracy would be to accept the ecological and political advantages of urban living. The third suggested revision is that green theorist ought not to see direct and representative democracy mutually exclusive. The fourth revision involves Greens accepting confederal and perhaps supranational political structures. A prominent green slogan is 'think globally, act locally'. The final, and most important, revision is a philosophical one. If convincing, it suggests that Greens should not think in terms of overriding principles or imperatives. ${ }^{33}$

\section{COMMUNITIES}

Robyn Eckersley has argued that ecological community required revolutionary, the active, responsible person-in-community called as homo communities. She suggests that the ultimate principle of eco-praxis is the need to maintain consistency between means and ends. These foster the development of self-help, community responsibility and free activity and are consistent with the ecotopian ideal of a loose federation of regions and

\footnotetext{
31. Lawrence E. Johnson, A morally deep world-an essay on moral significance and environmental ethics (U.S.A: Cambridge University Press, 1991).

32. Andrew Dobson, Green political thoughts (London and New York: Rutledge,2007).
}

33. Wouter Achterberg, Can liberal democracy survive the crisis? sustainability, liberal neutrality and overlapping consensus, in Andrew Dobson and Paul Lucardie (Ed), The Politics of nature- exploration in green political theory (London: Rutledge, 2003). 
communes In this context, the kinds of communities that represent ecological lifestyles are rural self-sufficiency farms, city farms.

\section{DIRECT ACTION}

Direct action to halt what protestors see as environmental degradation has become an increasingly prominent feature of the political scene in recent years, and it is carried out by an apparently disparate collection of people.

\subsection{Democracy or Authoritarianism}

North American writers such as Heilbroner (1974) and Ophuls (1977) appeared to argue that the environmental crisis was so dire that only strong government or authoritarian government is required. More recently, it has been suggested that there is a right way to live the green good life is incompatible with the value pluralism normally associated with (liberal) democracy. There are, then, both pragmatic and ethical roots to the palpable tension between radical green objectives and the democratic process. ${ }^{34} \mathrm{O}^{\prime}$ Riordan suggests that the present system of the liberal democratc system cannot be sustained: special interest groups tend to undermine resolute government which uses short term expediency to override long term commitments; political leaders prevaricate in the face of conflicting proposals and contradictory evidence; the authority of legislatures is eroded by the ability of special interest groups to evade regulation; citizens are weak when confronted with the power of the neo-corporate state, and lack of formation necessary to counter that power; and pluralism is predicated upon compromise, but fear of scarcity encourages confrontation and irresolution.

O'Riordan advocated four resolutions: A new global order, in which the current state system is dissolved and replaced by a single, global organization. Its proponents, according to an advanced communistic or socialistic one built on the goal of increasing material welfare, whatever the nature of the state. Centralized authoritarianism, in which all the problem of liberal democracy are replaced by a totalitarian state which sees the promotion of global ecological equilibrium as its predominant mission. The authoritarian commune which according to Heilbroner involves blending the religious orientation and military- style discipline characteristic of a monastery with the policies attempted in China. The anarchist solution, which goes further than the previous one because it promotes a society without a state..$^{35}$

\section{Values}

There is a predominant view that human beings are of exclusive moral significance though there are dissenting opinions. The problem is how best to utilize the nature and moral question concerned the implications for other humans. The non- human values are generally scaled on vertical rather than horizontal axis. Various reasons, religious and sentiments have been given for the supremacy of moral standing of human beings. Humans unlike others are considered morally superior. In recent years there is a debate on the revival of interest in the question of the values of non-human world. In the past also we find many instance of it. Plutarch, advocated a vegetarian diet and many non- western tradition recognize moral significance of natural world. The impact of the human activities on the non- human are evaluated like in Peter singer's book, animal liberation. Another group is concerned with the ethical significance of our actions affecting the environment. Their concerned is with ecosystem e.g. pollution, extinction of species. Extending humanity beyond humans and there is diversity of opinions to extend the moral universe. Now the argument arises is that there is common principles dealing with animals and human beings. Moral consideration is due to us because we have interests. But our interests are integral part of life process. Even animals, plants, species and ecosystem have interests which have moral significance. If human interests are to have any moral weight at all, then all genuine interests must be recognized. ${ }^{36}$

What drives environmental political thought and action is the green theory of value. According to this theory, something is especially valuable if it has come about through natural rather than through artificial human processes. The task of the political ecologist, then, is to work for the preservation of this 'natural value' through time. Goodin carefully distinguishes between this theory of value and a putative green theory of agency. Green also question the rising population. In terms of reducing overall consumption, there's nothing more effective than reducing the number of people doing the consuming. Greens are aware that some people in some countries consume much more than other people in other countries. The green sustainable society raises the issue of the

34. Andrew Dobson, Green political thoughts (London and New York: Rutledge,2007).

35. R.J Johnson, Environmental Problems: Nature, Economy and State ( London: Belhaven Press, 1989).

36. Lawrence E. Johnson, A Morally Deep World-An Essay on Moral Significance and Environmental Ethics ( New York: Cambridge University Press, 1991). 
role and place of technology. Greens blame scientific development for many of the ills it believes we now suffer and they are viewed as anti-technological and therefore as a call to return to a pre-technological age.

\section{Conclusion}

The chapter highlighted that only an integrated approach can solve the climate problem. The integrated approach includes economy, ecology, social stability, sustainability and spatial planning. This chapter highlights four environmental visions- market- liberal vision, institutionalis vision, bioenvrionemtalism and social green. It highlights technological strategy like using saving energy devices, clean development project and joint implementation projects. It also highlights the problem with the present development path and explore sustainable development as the possible strategy. Only collective action is effective. Eco-feminists advances their solution in term of developing feminists tendencies. Resource conservation is also an effective strategy. Further ecologists talk of developing ec0system which deals with ecological economy. Eco-marxists and ecosocialism can also act as solution to this acute crisis. There is also required a change in energy policy, transport policy and developing green principles. At the individual and community level voluntarinism, lifestyles and developing eco-values are good strategies. Ecologists also promote the idea of ecological citizenship and spiritual approach. Legislature can also help in managing the climate change by establishing environmental laws. Finally we can apply democractic or authoritarian means to save the climate as when required. 